\title{
Improve Creative Industry Competitiveness Penta Helix and Human Capital in Digital Era
}

\author{
Gendut Sukarno, ${ }^{1}$ Resa Rasyidah, ${ }^{2}$ Kholifatus Saadah ${ }^{3}$ \\ ${ }^{1}$ Economic and Business Department, Universitas Pembangunan Nasional "Veteran” Jawa Timur, \\ Indonesia \\ ${ }^{2}$ International Department, Universitas Pembangunan Nasional "Veteran" Jawa Timur, Indonesia \\ ${ }^{3}$ Cakra Studi Global Strategis, Universitas Airlangga, Indonesia \\ Corresponding Author's Email: sukarnogendut@yahoo.co.id
}

\begin{abstract}
As it predicted as one of the creative industry proponents, the culinary industry is growing rapidly in Indonesia. The culinary industry sub-sector grows because of cultural and lifestyle shifts, as well as technology development. It becomes one of the determining factors in the successfulness of the culinary business, especially in this digital area within offline to online shifting. This research aims to discuss about Penta Helix and Human Capital concepts in strengthening competitiveness which impacts the creative industry business performance on culinary industry sub-sector The population in this study were all managers/owners of the Surabaya culinary creative industry who collaborated with online delivery services (Go-Jek and Grab), with 75 respondents as the samples. The authors are using a data analysis technique with Partial Least Square (PLS). Based on the results of the research found that all dimensions (Academics, Business, Civil Society, Government, Media) are to be a gauge/indicator variable Penta Helix. Variable in human capital; competitiveness and business performance show that all of these indicators are valid and serve as indicators of the human capital, competitiveness, and business performance variables. Penta Helix, human capital, and competitiveness can provide a fair design contribution to business performance.
\end{abstract}

Keywords: Penta Helix, human capital, competitiveness, business performance

\section{INTRODUCTION}

The term creative economy was first introduced by John Howkins in 2001 in his book "The Creative Economy". Howkins developed the concept of a creative economy that links creativity and economics. It is based on the creative imagination of economic actors to increase the added value of a business idea. (Howkins 2001) The creative economy can play a role as a new source of strength for the Indonesian economy in the digital age. The creative economy is a strategic sector in national development in the future because it contributes significantly to the national economy. In fact, the President of the Republic of Indonesia, Joko Widodo plans to make the creative economy as the backbone of 
the Indonesian economy, which can create added value and coloring the image and cultural identity

According to statistics and surveys of the Creative Economy (2017), until the end of 2014, the creative economy was able to contribute 716 trillion Rupiahs, equivalent to 7.06 percent of total gross domestic product (GDP). The Indonesian Creative Economy Agency has mapped the potential for the creative economy in the regions. The sixteen creative economic sub-sectors that still need to be socialized are game application and development, architecture and interior design, visual communication design, product design, fashion, film, video animation, photography, craft, culinary, music, interaction, advertising, performance art, television, and radio. Of the 15 sub-sectors approved in the following table, three subsectors appear to have contributed greatly to the growth of the creative economy, namely culinary 32.4 percent; fashion 27.9 percent; and crafts 14.88 percent.

Table 1. Contributions of the Creative Economy against Gross Value Added in 2010-2013 (Billion Rupiahs)

\begin{tabular}{|c|l|r|r|r|r|}
\hline Sector & \multicolumn{1}{|c|}{ Descriptions } & $\mathbf{2 0 1 0}$ & $\mathbf{2 0 1 1} *$ & $\mathbf{2 0 1 2}^{* *}$ & \multicolumn{1}{c|}{$\mathbf{2 0 1 3}^{* * *}$} \\
\hline 1 & Advertising & $2,534.7$ & $2,896.6$ & $3,168.3$ & $3,754.2$ \\
\hline 2 & Architecture & $9,243.9$ & $10,425.6$ & $11,510.3$ & $12,890.9$ \\
\hline 3 & Art market & $1,372.1$ & $1,559.5$ & $1,737.4$ & $2,001.3$ \\
\hline 4 & Craft & $72,955.2$ & $79,516.7$ & $84,222.9$ & $92,650.9$ \\
\hline 5 & The design & $19,583.2$ & $21,018.6$ & $22,234.5$ & $25,042.7$ \\
\hline 6 & Fashion & $127,817.5$ & $147,503.2$ & $164,538.3$ & $181,570.3$ \\
\hline 7 & Film, video and photography & $5,587.7$ & $6,466.8$ & $7,399.8$ & $8,401.4$ \\
\hline 8 & Interactive game & $3,442.6$ & $3,889.1$ & $4,247.5$ & $4,817.3$ \\
\hline 9 & Music & $3,972.7$ & $4,475.4$ & $4,798.9$ & $5,237.1$ \\
\hline 10 & Performing Arts & $1,897.5$ & $2,091.3$ & $2,294.1$ & $2,595.3$ \\
\hline 11 & Publishing and printing & $40,227.0$ & $43,757.0$ & $47,896.7$ & $52,037.6$ \\
\hline 12 & Computer services and software & $6,922.7$ & $8,068.7$ & $9,384.2$ & $10,064.8$ \\
\hline 13 & Radio and television & $13,288.5$ & $15,664.9$ & $17,518.6$ & $20,340.5$ \\
\hline 14 & Research and development & $9,109.1$ & $9,958.0$ & $11,040.9$ & $11,778.5$ \\
\hline 15 & Culinary & $155,044.8$ & $169,707.8$ & $186,783.3$ & $208,632.8$ \\
\hline & Amount of creative economy & $472,999.2$ & $526,999.2$ & $578,760.6$ & $641,815.5$ \\
\hline
\end{tabular}

Note: *) Temporary numbers **) Very Temporary numbers ***) Very very temporary numbers Source: BPS

From Table 1 it appears that the culinary sub-sector is increasing every year, with a slightly higher contribution rate than the fashion sector. The culinary sub-sector won the biggest contribution list with the achievement of Rp. 208.6 trillion or equal to $33 \%$ of the total value added of the creative economy in 2013. 
The culinary sub-sector grew due to cultural and lifestyle shifts. One of the lifestyles of today's generation that is driving the increasing culinary business is the habit to hang out in food stalls. Today's culinary business trends continue to gain interest. Apart from the fact that food is a basic need that is always sought, technological development is also one of the factors that determine the success or failure of a culinary business, which is a transition from offline to online.

The existence of an online business is slowly but more certain, will erode conventional business so that an entrepreneur must be able to think about how to survive. The culinary industry is one of the informal sectors which is developing rapidly. The high penetration of the Internet and mobile users in Indonesia has opened wide doors for online business opportunities such as the presence of more and more e-commerce players and marketplaces in the country, including the culinary business.

The presence of digital technology brings many opportunities for culinary businesses. Social media has the potential to market products effectively, even more effectively compared to old marketing models, especially physical/offline advertising. Technology mastery is an important skill that business people must possess. Culinary businesses are competing to provide culinary as interesting and unique as possible in order to get more attention from the younger generation. If it has received attention in cyberspace or in other words it has become viral, the marketing process will automatically increase rapidly and the culinary marketed will become a rush of curious people. Various innovations and promotions have been launched by culinary businesses. Starting from giving unique and earcatching food names like Mie Setan (Satan Noodles), Jus Bunuh Diri (Suicide Juice), Gudeg Mercon (Firework Gudeg) and so on; creating new menus such as noodles that can change color or black kebabs; to simply follow the latest food trends such as the use of salted egg sauce on an existing menu. All these innovations are then campaigned through social media to become viral.

In addition to social media, startup trends that are on the rise in Indonesia also give birth to new innovations, especially in making applications to overcome certain problems. People have almost unlimited culinary choices, not only those close to their homes, but also long distances. The emergence of various online motorcycle taxi applications in collaboration with various merchants has become a stepping stone for the food distribution (delivery) system. Buyers simply move their fingers over the device screen to select and order the desired menu, then wait for the food to be delivered to the house without having to bother crashing the traffic and waiting for the queue to be served at the place to eat. In addition to not having to bother to leave the house, the available payment methods also vary, ranging from the payment options in cash (COD/Cash on Delivery)), bank transfers with a virtual account, the use of the redeem points system, to credit cards. All these conveniences certainly increase the turnover of culinary business people.

The rapid growth of the culinary industry as one of the informal sectors cannot be separated from the involvement of several Helix/Elements, both from 
academics, business people, government and society/social as well as the role of the media. The involvement of the private sector and associations in the development of tourism/culinary and shopping industries in Indonesia is often carried out by the Ministry of Tourism (Ministry of Tourism). Even in real developments, the private sector and associations are always involved as mediators and integrators drawn directly from the elements (helix).

The concept of a synergy of some of the parties concerned in fostering the entrepreneurial sector is Penta Helix. This Penta Helix element was originally in the form of a Triple Helix with elements of Academics, Business Sector, Government, which was then added with one element, Civil Society, to become a Helix Quadruple, to accommodate people's perspectives, in this case a "media and culture-based society" has also been an integral part of innovation in the $21 \mathrm{st}$ Century (Park, 2013).

Research studies related to Penta Helix include the concept of innovators (Park, 2013) which was originally in the form of Triple Helix, then added with elements of Civil Society so that it becomes a Quadruple Helix, which is then equipped with elements of Media, which became Penta Helix. Similar research by Han Woo Park (2013), Innovation in Creative Industries: From the Quadruple Helix Model to Systems Theory. Other research by Mulyana, Sutapa (2014), Improving the Capability of Innovation, Competitive Advantage and Performance through the Helix Quadruple Approach: Study in the Fashion Sector Creative Industry. Similar research by Alrence Santiago Halibas (2017) The Penta Helix Model of Innovation in Oman: An HEI Perspective.

In order to be able to compete in this digital era, Indonesia seems to need to prepare properly in relation to improving Human Capital. This can be seen in the Human Development Index (HDI) indicator in Indonesia. The 2016 Human Development Report released by the United Nations Development Program (UNDP) noted that Indonesia's Human Development Index (HDI) in 2015 ranked 113, down from 110 in 2014. UNDP considers that the government of the Republic of Indonesia still has a number of homework to solve the gap which is one of the factors influencing HDI. During the period 1990-2015, Indonesia's HDI experienced an average increase of $1.07 \%$ per year. In comparison, Thailand, ranked 87 th, experienced an average HDI growth of $1.02 \%$ per year, lower than Indonesia. Conversely, Vietnam which is currently ranked 2 below Indonesia experiences an average HDI growth of $1.45 \%$ per year (1990-2015). Indonesia's HDI figure is still relatively low, which is only 0.62 and is incorporated in the group of countries with the HDI medium human development category. HDI Indonesia is still far below Singapore (0.89) and Brunei (0.85) which are able to appear very advanced in the group of countries with the HDI category of very high human development. Malaysia is also quite far above Indonesia with an HDI of 0.76 and belongs to the category of high human development countries.

The importance of the role of Human Capital was also conveyed by the Minister of Finance Sri Mulyani. She stated that national economic growth could no longer rely solely on commodities, but began to shift to human 
resources/human capital (accessed in Media Indonesia: Saturday, June 23, 2018, 13.15). Through the state budget instrument (APBN), the government wants to play a role in the development of the digital economy in the country.

Research references on the role of Human Capital in sustaining the performance of small industries are strengthened by research conducted by Santos Helena et.al (2011) in his research entitled "System of Innovation and Innovative SMEs: A Model to Measure the Intellectual Capital of SMEs". The research is in line with research conducted by Seleim et al (2007), and F-Jardo'n and Markos (2009). Other research by Sharabati, et al (2010), shows that the variables of Intellectual Capital (IC including Human Capital) have a significant and positive effect on Business Performance (BP). Cabrita and Bontis's research (2007) also states the same results that each IC variable (Human Capital, Structural Capital, and Relational Capital) interacts with BP.

The strong synergy of Penta Helix and the strength of Human Capital will affect the strength of the culinary business competitiveness. Competitiveness is productivity that is defined as output produced by labor (Porter, 1990). Competitiveness is a concept that refers to the ability of a company to compete with other companies to create value. There is no single indicator that can be used to measure competitiveness which is very difficult to measure (Markovics, 2005). Competitiveness can be created or enhanced by applying appropriate competitive strategies, one of which is by managing resources effectively and efficiently. In addition, the determination of the right strategy must be adjusted to all activities of the company's functions, so that it will create company performance in accordance with what is expected even more and can produce value. According to Tambunan (2008a), highly competitive MSMEs are characterized by: (1) an increasing tendency of the growth rate of production volume, (2) an everincreasing share of the domestic market and / or export market, (3) for the domestic market, not only serving only local markets but also national ones, and (4) for export markets, serving not only in one country but also many countries. There are limitations and gaps in the important role of SMEs in the Indonesian economy and the impact on business performance that is not yet maximal, it is necessary to have a strategy to increase the competitiveness of SMEs in the creative industries. Efforts to increase competitiveness that have an impact on the Business Performance of the creative industries can be influenced by market orientation and entrepreneurial orientation. Market orientation and entrepreneurial orientation are correlated but the constructs are different. Market orientation reflects the extent to which strategic market planning is driven by customers and competitor intelligence. The entrepreneurial orientation reflects the extent to which the company's growth goals are driven by the identification and exploitation of untapped market opportunities (Baker \& Sinkula, 2009).

Based on the empirical studies above, the author is interested in synergizing the concept of Culinary Business Competitiveness Acceleration through the role of Penta Helix and human capital to improve the business performance of creative industries. 


\section{LITERATURE REVIEW}

The development of technology is a part of globalization, a concept that offers convenience in every aspect of everyday human life in the world nowadays. Some aspects of life affected by technological developments such as eating, drinking and even leaving for work or school. The resulting impact tends to be positive, globalization makes it easy for humans to carry out their activities, although, it must be remembered that globalization itself is a double-edged sword that also provides losses at the same time. Profits can be added and losses can be minimized by humans themselves, as agents of technological development within the framework of globalization, with strategies and mechanisms arranged in such a specific way. This research focused to see the impact of technological developments in globalization on industrial development, especially the culinary creative industry and also those who are influential in developments and shifts.

Creative industries are "different" forms of the industry compared to conventional industrial concepts; knowledge and information factors that produce creativity, play an important role compared to physical actions (Parrish, n.d). The concept of the digital economy itself is close to the creative industry; technological development encourages individuals to get a lot of information from a broad source and then form creativity that is different from before. In the process of running the digital economy, the creative industry will go around in a dynamic concept, innovative and tend not to be obsolete (Warren \& Fuller, 2009). These concepts create the creative industry concept; no longer stay in the matter of "getting a profit", but innovation also needed in the process. In addition, the continuous processing of information that encourages projects and industrial actors is no longer based on existing concepts; it is the development that will shape them into something new. It's also important to remember that in the dynamics of the creative industry and the digital economy, there are conditions that must be considered in order to avoid misleading between one concept and another. It could be like the form of attention to the universe of cross-linked industries, creative industries will provide many new things and must be processed so as not to mix between aesthetics and social values (Warren \& Fuller, 2009). It could be that one of the new innovations in the industry turns out to be colliding with the appropriateness norm of a certain place; creative industry players who utilize the digital economy must be aware if this happens in the future.

When discussing the digital economy, technological development, and creative industries in the Southeast Asian region, Singapore is a great example that related to the linkages of these three things. Singapore is ranked second in the world in terms of computer literacy and technology in 1995 (Tan, 1999). Let's imagine when countries in the same region, such as Vietnam and Cambodia, in the same year were still struggling with poverty and domestic turmoil, Singapore was already in the elite ranks of the country that succeeded in utilizing globalization and economic development to advance their country's industries. The well- 
developed digital economy in Singapore is inseparable from the role of the Singapore government for having full efforts to build the infrastructure supporting the formation of the digital economy. In addition, good coordination between the public sector and the Singapore government to establish the National Information Infrastructure (NII); an integration result related to the entire development of information in Singapore, it can't be ignored in assessing Singapore's success (Tan, 1999). Great collaboration from the private and public sectors to continue to maintain and provide updates related to new things that will affect the concept of the digital economy and NII to the future, a good example in seeing the role of stakeholders in Singapore in order to advance the country through the corridor of the creative economy.

The development of the digital economy and creative industries build the concept of digital collaborative consumption (Saadah et al., 2017). Digital collaborative consumption is an economic activity based on leasing, selling, exchanging or even sharing services and products that are not owned by a single owner (Bostman \& Rogers 2010 in Saadah et al., 2017). These activities are different from conventional economic activities, where digital collaborative consumption will be very dependent on technology, especially information and communication. The argument put forward by the author shows that lifestyle is the biggest driving factor in increasing this digital collaborative consumption. Globalization that provides convenience tends to make individuals use the easiest and most profitable way for themselves, and also for others. There are at least three types of digital-based collaborative consumption according to Botsman \& Rogers (2010), namely: (1) mechanisms that are more likely to sell services than physical products; (2) re-distribution markets; and (3) a lifestyle that can collaborate, so they can find many individuals with the similar lifestyle. The similarity in lifestyle then provides a new market that can provide the needs and desires of consumers. In collaborative consumption, actors who play a role will be very much compared to only limit to consumers and producers such as conventional economic activity. The private sector such as companies and third parties such as non-governmental organizations have a huge role in consumption by consumers; given that the creative economy has many innovative dynamics involving all elements of society in this globalization era.

Many elements involved in the digital economy and the creative industries, those can be confusing in mapping the cause-effect relationships and also management going forward. In this paper, the authors used Penta-helix model. Penta-helix itself is one mechanism that involves five stakeholders and explains its relationship into a specific mechanism. Innovation is one aspect that becomes valuable in the creative industry. In making innovation happens, collaboration is needed from several supporting elements, both in terms of communities and nonprofit organizations related to these innovations (Muhyi et al., 2017). Muhyi et al. (2017) in his research about the Penta helix collaboration model in developing the flagship industry in Bandung examines that the five penta-helix elements have a huge role in developing the flagship industry in Bandung. So, it brings enormous 
benefits for the Bandung Government itself. Muhyi et al. (2017) also found that aspects of the media and academics had a large role in industrial development through the penta-helix model; when both aspects are sometimes ignored by researchers and practitioners in terms of industry. The two elements not always come directly to the field, but the power of literacy and digitalization as now, gives rise to evidence that elements of media and academics cannot be ignored in the penta-helix model, especially watching the result in the Bandung.

In line with the research in Bandung, Yunas (2019) revealed that the penta-helix model was successfully implemented in three villages in East Java through the Lumbung Ekonomi Desa program. The Lumbung Ekonomi Desa itself is a centralized economic empowerment mechanism for rural communities. The mechanism starts from potential mapping, management to digitalizing the economy for marketing. To complete this mechanism, it requires synergic collaboration in the form of penta-helix, consisting of government, regional apparatus, community, private sector, media and academics in higher education. With comprehensive collaboration, Lumbung Ekonomi Desa in two villages in Jombang and one village in Nganjuk can run smoothly. It can't be separated from the synergy of the stakeholders too. Yunas (2019) in her research also showed that each element of stakeholders, such as local communities, has a desire to carry out a collaborative collaboration so that the mechanism of the penta-helix is able to work.

From the explanation above, it can be concluded that the penta-helix collaboration actually goes hand in hand with the digitalization of the economy and the creative industries. Because in the creative industry itself the involvement of actors beside business people and consumers is important. Innovation will not work in the creative industry without the support of other stakeholders. The government has the authority to form rules, the community has a role to maintain and oversee the innovation, business is the main actor in the course of economic activity, academics will participate at the level of research which can be disseminated by the media. Thus, the five actors have their respective roles and will be more successful if the collaboration happened in the creative industry.

\section{RESEARCH METHOD}

\section{Population and Sample}

This research uses data collection methodology in the form of population and sample. The population in this study were all managers/owners of the Surabaya Culinary creative industry who collaborated with ONLINE delivery services (Go-Jek and Grab), with a sample of 75 respondents.

\section{Analysis Techniques}

The data analysis technique used in this research is Partial Least Square (PLS). PLS according to Wold H (1982) is a powerful analysis method because it is not based on many assumptions. PLS method has its own advantages including the data do not have to be multivariate normally distributed (indicators with 
category, ordinal scale, the interval to ratio can be used on the same model) and the sample size does not have to be large.

\section{RESEARCH RESULTS AND DISCUSSION Validity Analysis Measurement Model and Indicator Validity (Outer Model)}

In this paper, the relationship model between variables and indicators in the measurement model for the variables called Penta Helix, Human Capital, Competitiveness, and Business Performance variables is based on the outer loadings table. Based on outer loadings, the Penta Helix variable shows all dimensions (Academics, Business, Civil Society, Government, Media) having a loading factor greater than 0.5 and the significance value (p-values) smaller than 0.001 , so the dimensions of Academics, Business, Civil Society, Government, Media is a gauge/indicator of the Penta Helix variable. Likewise, the Human Capital variable produces that all indicators have a factor loading greater than 0.5 and the significance value ( $\mathrm{p}$-values) is smaller than 0.001 , so it meets convergent validity. That is, all of these indicators are valid and become a measure (indicator) of the Human Capital variable. The same thing is found in the variable Competitiveness shows that all indicators have a factor loading greater than 0.5 and significance value (p-values) smaller than 0.001 , so that it meets convergent validity. It means, all of the indicators are valid and become a measure (indicator) of the Competitiveness variable. The Business Performance variable produces that all indicators have a factor loading greater than 0.5 and the significance value (pvalues) is smaller than 0.001 , so that it meets convergent validity. It means, all of these indicators are valid and become a measure (indicator) of Business Performance variables.

\section{Average Variance Extracted (AVE)}

Table 2. Average Variances Extracted (AVE)

\begin{tabular}{|l|c|}
\hline & Average Variances Extracted (AVE) \\
\hline Penta Helix : & 0.593 \\
\hline -Academics & 0.776 \\
\hline -Business & 0.713 \\
\hline -Civil Society & 0.734 \\
\hline -Government & 0.793 \\
\hline -Media & 0.648 \\
\hline Human Capital & 0.606 \\
\hline Competitiveness & 0.689 \\
\hline Business Performances & \\
\hline
\end{tabular}

Source: data processing result by the authors 
The next measurement model is the Average Variant Extracted (AVE) value, which is indicating the magnitude of the indicator variance contained by the latent variable. The test results show that the AVE value for the construct (variable) Penta Helix, Human Capital, Competitiveness and Business Performance has a value greater than 0.5 , so it is valid.

\section{Reliability Analysis Composite Reliability}

Construct reliability is measured by the value of composite reliability; the construct is reliable if the value of composite reliability is above 0.70 so the indicator is called consistent in measuring its latent variable. The test results show that the construct (variable) Penta Helix, Human Capital, Competitiveness, and Business Performance has a composite reliability value greater than 0.7 , so it means that those are reliable.

Table 3. Composite Reliability

\begin{tabular}{|l|c|c|}
\hline & $\begin{array}{c}\text { Composite Reliability } \\
\text { Coefficients }\end{array}$ & $\begin{array}{c}\text { Cronbach's Alpha } \\
\text { Coefficients }\end{array}$ \\
\hline Penta Helix : & 0.825 & 0.733 \\
\hline -Academics & 0,912 & 0.823 \\
\hline -Business & 0.882 & 0.754 \\
\hline -Civil Society & 0.892 & 0.765 \\
\hline -Government & 0.920 & 0.816 \\
\hline -Media & 0.847 & 0.728 \\
\hline Human Capital & 0.885 & 0.837 \\
\hline Competitiveness & 0.869 & 0.773 \\
\hline Business Performances &
\end{tabular}

Source: data processing result by the authors

\section{Structural Model Testing (Inner Model)}

Structural model testing is processed by looking at the R-Square value which is a goodness-fit test of the model. Testing the inner model can be seen from the R-Square value on the equation between latent variables. The value of R2 explains how much exogenous (independent/independent) variables in the model are able to explain endogenous (dependent/dependent) variables.

Table 4. R-Square Coefficients

\begin{tabular}{|l|c|}
\hline & R-Square \\
\hline Penta Helix & \\
\hline Human Capital & 0.602 \\
\hline Competitiveness & 0.224 \\
\hline Business Performances & \\
\hline
\end{tabular}

Source: data processing result by the authors 
Overall $\mathrm{R}^{2}$ value $=1-(1-0.602)(1-0.224)=0.6912$. This can be interpreted that the model is able to explain the phenomenon/problem of Business Performance by $69.12 \%$. While the rest $(30.88 \%)$ is explained by other variables (besides Penta Helix, Human Capital, and Competitiveness) that have not been included in the model and error. That is, Business Performance is influenced by Penta Helix, Human Capital, and Competitiveness by $69.12 \%$, while $30.88 \%$ is influenced by non-Penta Helix variables, Human Capital, and Competitiveness

\section{CONCLUSIONS AND RECOMMENDATIONS}

\section{Conclusions}

- The Penta Helix variables show all dimensions (Academics, Business, Civil Society, Government, Media) which is a gauge/indicator of the Penta Helix variable.

- Human Capital variables produce that all indicators are valid and become a measure (indicator) of Human Capital variables.

- Competitiveness Variables indicate that all indicators are valid and become a measure (indicator) of Competitiveness variables.

- Business Performance Variables produce that all indicators are valid and become a measure (indicator) of Business Performance variables.

- The test results indicate that the AVE value for the Penta Helix construct, Human Capital, Competitiveness and Business Performance has a valid value.

- The test results show that the Penta Helix construct, Human Capital, Competitiveness, and Business Performance have a reliable composite value.

- Penta Helix, Human Capital, and Competitiveness are able to provide a fairly strong contribution to Business Performance.

\section{Recommendations}

- Academics, especially universities that have a Food Technology Study Program to provide assistance in the study of nutrition, food hygiene with more intense than before.

- The media, in this case, the Ministry of Communication and Information, should provide regulations that provide protection for online transportation in cooperation with the culinary business.

- It is expected that there is a more integrated synergy in the Penta helix, meaning that the involvement, attention, and role of the academics, business, civil society, government, media on the existence of culinary business is more controlled, more controlled, more precise as needed and used in management culinary business. 


\section{BIODATA}

Dr. Drs. Ec. Gendut Sukarno, MS, CHRA is a lecturer of human resources management and empowerment, performance management, and strategy management in Management Dept., UPN "Veteran" Jawa Timur, Surabaya, Jawa Timur, Indonesia. Completed his Doctoral Degree at the Universitas Kristen Satya Wacana in 2016. He has research interest mainly in human resources. He can be reached through the e-mail: sukarnogendut@yahoo.co.id

Resa Rasyidah is a lecturer of international business, tourism in international relations and international organizations in International Relations Dept., UPN "Veteran" Jawa Timur, Surabaya, Indonesia. Completed her master degree in International Relations at the Universitas Airlangga, with a degree M.Hub.Int. Her research interest include international business and international organizations, also tourism in international business studies. Resa Rasyidah can be reached through the e-mail: resa.rasyidah@gmail.com

Kholifatus Saadah is an editor in Global \& Strategis, a national accreditated journal published by Cakra Studi Global Strategis, Universitas Airlangga. Completed her master degree in International Relations at the Universitas Airlangga, with a degree M.Hub.Int. In her graduate school, she has a concern to international business and international organization as well as global civil society. Completed her undergraduate program in the field of International Relations at Universitas Airlangga in 2015 with a degree S.Hub.Int and a thesis entitles The Evolution of ASEAN Political and Security Community 1991-2015. When she's still undergraduate student, Kholifatus is active in writing and at a conference mainly related to ASEAN and the issue of state sovereignty. Kholifatus Saadah can be reached through the e-mail: kholifatus.saadah21@gmail.com

\section{REFERENCES}

Anonim, (2014). Badan Pusat Statistik, "Kontribusi Ekonomi Kreatif terhadap PDB Indonesia $2010 \quad$ - $2013 \quad$," http://gov.indonesiakreat if.net/research/kontribusi - ekonomi - kreatif - terhadap - pdb - indonesia/ (accessed at 3 Juni 2014)

Baker, WE. Sinkula, JM, (2005). The Complementary Effects Of Market Orientation and Entrepreneurial Orientation On Profitability In Small Business, Journal Of Small Business Management, Vol. 47 (4), pp.443-464.

Cabrita, Maria do Rosario., Jorge Landeiro de Vas., and Nick Bontis, (2007). Modelling The Creation of Value From Intellectual Capital : A Portuguese Banking Perspective, Internationa Journal Knowledge and Learning. Vol. 3, Nos. 2/3, pp. $266-280$. 
Halibas, A. S., Sibayan, R. O., \& Maata, R. L. R. (2017). The penta helix model of innovation in Oman: An HEI perspective. Interdisciplinary Journal of Information, Knowledge, and Management, 12, 159-172. Retrieved from http://www.informingscience.org/Publications /3735

Howkins, John (2001). The Creative Economy. Penguin

Markovics, K. (2005). Competitiveness of Domestic Small and Medium Enterprises in the European Union. European Integration Studies, Miskolc, 4(1), 13-24. Markovics, K. (2005). Competitiveness of Domestic Small and Medium Enterprises in the European Union. European Integration Studies, Miskolc, 4(1), 13-24.

Media Indonesia : (Sabtu, 23 Juni, 2018, 13.15), Sri Mulyani: Tidak Investasi Sumber Daya Manusia, Mereka Tak Akan Berkembang

Muhyi, H. A., Chan, A., Sukoco, I., \& Herawaty, T. (2017). The Penta Helix Collaboration Model in Developing Centers of Flagship Industry in Bandung City.

Mulyana, Sutapa, (2014). Peningkatan Kapabilitas Inovasi, Keunggulan Bersaing dan Kinerja melalui Pendekatan Quadruple Helix: Studi Pada Industri Kreatif Sektor Fashion, Jurnal Manajemen Teknologi, Vol.13 | No.3 | 2014

Park, H.W. (2013).Transition from the Triple Helix to N-Tuple Helices? An Interview with Elias G. Carayannis and David F.J. Campbell. Budapest, Hungary: Akadémiai Kiadó

Parrih, David. (n.d). Creative Industries Definition [online] https://www.davidparrish.com/creative-industries-definitions/ [accessed at 29 October 2019)

Porter, M.E. (1980). Competitive Strategy: Techniques for Analyzing Industries and Competiors. Free Press, New York/Collier Macmillan, London.

Saadah, K., Yasmine, S. E., \& Mubah, A. S. (2017). Digital collaborative consumption and social issues: The clash of taxi and Uber driver in Surabaya and Taipei. Masyarakat, Kebudayaan dan Politik, 30(4), 333-343.

Santos, Helena. (2012). System of Innovation and innovative SMEs: A Model to Measure the Intellectual Capital of SMEs, Proceedings of the 4th European Conference on Intellectual Capital Arcada University of Applied Sciences Helsinki Finland 23-24 April 2012, p.411-420

Seleim, Ahmed., Ahmed Ashour., and Nick Bontis. (2007). Human Capital and Organizational Performance: A Study Egyptian Software Company. Management Decision. Vol 45, No 4., pp 789 - 801 
Sharabati, Abdel-Aziz Ahmad., Shawqi Naji Jawad., and Nick Bontis. (2010). Intellectual Capital and Business Performance in The Pharmaceutical Sector of Jordan. Management Decision. Vol 48. No. 1. pp. 105 - 131

Tambunan, T.T.H., (2008a). "Ukuran Daya Saing Koperasi dan UMKM", Background Study, RPJM Nasional Tahun 2010-2014 Bidang Pemberdayaan Koperasi dan UKM Bappenas. http://www.kadinindonesia.or.id [accessed at 8 September 2010].

Tan, M. (1999). Creating the digital economy: Strategies and perspectives from Singapore. International Journal of Electronic Commerce, 3(3), 105-122.

Warren, L., \& Fuller, T. (2010). Capturing the dynamics of co-production and collaboration in the digital economy. Leonardo, 43(2), 200-201.

Wold H. (1982). Soft modeling: the basic design and some extensions, in Systems under Indirect Observation, Part 2, Jöreskog K.G., Wold H. (eds). NorthHolland, 1-5

Yunas, N. S. (2019). Implementasi Konsep Penta Helix dalam Pengembangan Potensi Desa melalui Model Lumbung Ekonomi Desa di Provinsi Jawa Timur. Matra Pembaruan: Jurnal Inovasi Kebijakan, 3(1), 37-46. 